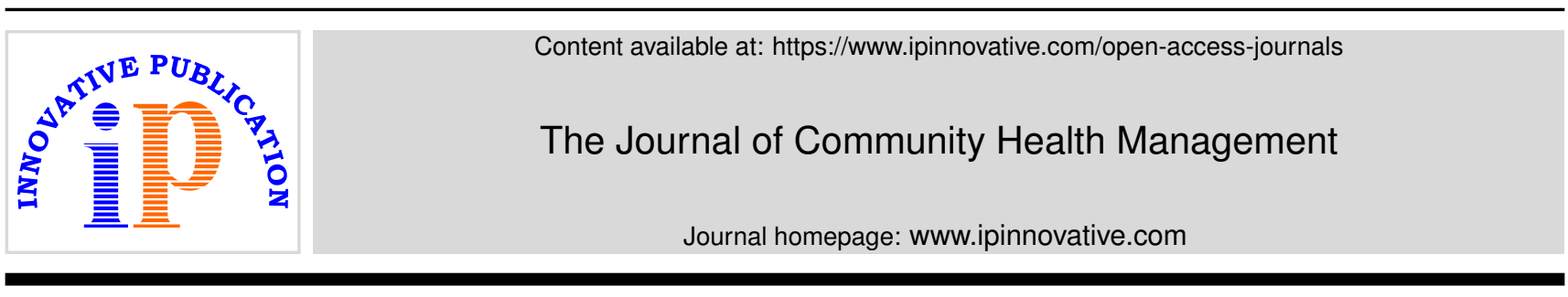

\title{
Editorial
}

\section{Nasal ACE 2 receptors' the gateway to COVID 19?}

\author{
Badrinarayan Mishra ${ }^{1, *}$, S C Mohapatra ${ }^{2}$ \\ ${ }^{1}$ Dept. of Community Medicine, Ruxmaniben Deepchand Gardi Medical College, Ujjain, Madhya Pradesh, India \\ ${ }^{2}$ Dept. of Community Medicine, SGT University, Gurugram, Haryana, India
}

\section{A R T I C L E I N F O}

Article history:

Received 25-09-2020

Accepted 27-09-2020

Available online 15-10-2020

Keywords:

ACE 2 receptors

Olfactory pathway

COVID 19

ACE antagonist lavage

\begin{abstract}
A B S T R A C T
Understanding the basic pathophysiology of the current spiralling COVID 19 pandemics is sin aqua none to its control. Amidst the neverending circulating hypotheses the role of ACE (Angiotensin-Converting Enzyme) 2 receptors, especially the nasal ones are is apparently leading the pack. Here we put forth the current evidences in its' support which may tinkle many cogent minds.

(C) 2020 Published by Innovative Publication. This is an open access article under the CC BY-NC license (https://creativecommons.org/licenses/by-nc/4.0/)
\end{abstract}

\section{Introduction}

COVID 19, is considered as 'the most devastating new year's gift' and the 'Dark Lord' that has emerged from China. ${ }^{1}$ WHO's (World Health Organization) official confirmation of its existence in $31^{\text {st }}$ December 2019 and the subsequent multidomain impact has unsettled the world beyond comprehension. This 'Lord Voldemort' of $21^{\text {st }}$ century has made its presence felt in every spere of human life. ${ }^{1}$ The impact of the devastating pandemic is pretty evident by the very fact that over 3,70,19,381 number of cases, and 10,69,953 deaths being reported globally by the time this article is drafted (10/10/2020). The top two democracy of the world i.e. USA and India are paying a heavy price. While the number of cases and reported deaths from COVID 19 in USA is 77,25,717 and 2,13,876; India is no way behind, with its total tally hovering over $70,00,000$ cases and 1,07,4161 deaths.

This pandemic has many uniqueness. The ambiguity surrounding its time and place of occurrence is equally complemented by its varying nature of manifestations. The myths and hypotheses are in abundance. We may not exactly

\footnotetext{
* Corresponding author.

E-mail address: badrinmishra@gmail.com (B. Mishra).
}

blame any sect keeping the novelty that surrounds this novel virus. As the world commune gathers empirical evidences many theories begin to unfold which will be of quite some help to solve this ever-enlarging puzzle.

The accumulation of evidences in favour of ACE 2 nasal receptors on which the COVID 19 virus piggy rides is gathering momentum. These hypotheses 'that associates Angiotensin-Converting Enzyme (ACE)-2 to SARS-CoV2(COVID 19 virus)' have two components:

1. The first hypothesis $\left(\mathrm{H}_{1}\right)$ postulates the role of nasal/respiratory epithelial ACE 2 receptors as active facilitators for SARS-CoV-2 entry in to human body and their role in disease presentation.

2. The second hypothesis $\left(\mathrm{H}_{2}\right)$ postulates that in such scenario, the use of ACE-2 agonists and Angiotensin Receptor Blockers (ARBs) as potential treatment and infection prevention modalities.

\subsection{Evidences supporting hypothesis (H1)}

The members of corona virus group exhibit high degrees of genomic and clinical similarities. ${ }^{2-4}$ Researchers have demonstrated that the main human receptor to which human 
pathogenic coronaviruses binds in order to get an entry to the host cells is via ACE 2 nasal and oropharyngeal receptors. Especially SARS-CoV-2 (The Novel Corona Virus or COVID 19) has a 10 to 20-fold higher affinity for ACE 2 as compared to its other siblings. This is because of the binding affinity of Cryo-EM spike of the virus that picks on the ACE 2 receptors. ${ }^{4}$ The respiratory, intestinal and renal and vascular endothelium and the epithelial cells of brain are the main sites for ACE 2. The protein-ligand binding of ACE 2 and COVID 19 virus on these dominating sites amply explains the different clinical presentation modalities associated with the disease. ${ }^{5-7}$ Facts like the lower incidence rate, mild clinical presentation and high asymptomatic state in children < $10 y$ rs further strengthens this hypothesis as the number of ACE 2 receptors specially in nasopharyngeal and olfactory region among them are fairly less in comparison to their older counterparts. ${ }^{8,9}$ Furthermore, the high concentration of ACE 2 in aging population, diabetic, hypertensive, asthmatic and obese persons and the increased propensity of the disease in these population renders imperial support to the hypothesis under scanner. ${ }^{10}$

\subsection{Evidences supporting hypothesis (H2)}

The primary mode (>90\%) of COVID 19 spread is by inhalation of aerosols/droplets expelled from infected persons. The virus starts multiplication in ACE 2 target cells of nasal mucosa before spreading further down the respiratory tract. ${ }^{3,11}$ But the asymptomatic rate for this disease is close to $60 \%$, a huge proportion that can act as hidden spreaders. ${ }^{12}$ This makes the role of prevention further important. An add on to the existing preventing practices of social distancing, mask and sanitization, specially by soap water (this neutralizes/breaks the lipoidal surface structure of the virus even at $1 \%$ concentration) can be the use of ACE inhibitors as lavage medium in the form of diluted solutions for routine nasal and oropharyngeal lavage that can minimize host virus contact period and at the same time prevent the ligand binding by acting as an inhibitor/barrier at virus inoculation sites. ${ }^{13}$ Some scientists have proposed that the solution should have a $\mathrm{pH}$ of 5.0 as ACE 2 becomes in active at this acidic condition hence making the virus binding ineffective. ${ }^{14}$ ACE 2 receptor testing also become imperial for individuals with severe anosmia but negative c-PCR report as rapid polymerase chain reaction (PCR) testing has a high false negative rate and anosmia is a strong clinical sign for Covid 19 infection in presence of other supportive findings. ${ }^{14}$ Few things that has to be kept in mind are the tritiated effective concentration of ACE 2 blockers, monitoring the heart rate and blood pressure (BP) of the individuals, and using adequate pressure (120 mbar) and angulation (upwards at about $45^{\circ}$ ) for delivery of the lavage medium. ${ }^{15}$ This approach may reduce the viral load thereby reducing the chance of acquiring the disease. The benefits once documented can be a boon to elderly, immunosuppressed and patients suffering from cancers as a pharmaco-based primordial support in paddling the dark horse.

\section{Conflict of Interest}

None.

\section{References}

1. Rowling's JK. Chapter 13, The Very Secret Diary. In: Harry Potter and the Chamber of Secrets; 1998.

2. Ciaglia E, Vecchione C, Puca AA. COVID-19 Infection and Circulating ACE2 Levels: Protective Role in Women and Children. Front Pediatr. 2020;8:206.

3. Lu R, Zhao X, Li J, Niu P, Yang B, Wu H. Genomic characterisation and epidemiology of 2019 novel coronavirus: implications for virus origins and receptor binding. Lancet. 2020;395:565-74.

4. Wrapp D, Wang N, Corbett KS, Goldsmith JA, Hsieh C, Abiona O, et al. Cryo-EM structure of the 2019-nCoV spike in the prefusion conformation. Sci. 2020;367(6483):1260-3.

5. Hamming I, Timens W, Bulthuis MLC, Lely AT, Navis GJ, van Goor H. Tissue distribution of ACE2 protein, the functional receptor for SARS coronavirus. A first step in understanding SARS pathogenesis. J Pathol. 2004;203(2):631-7.

6. Chen M, Shen W, Rowan NR, Kulaga H, Hillel A, Ramanathan M. Elevated ACE2 expression in the olfactory epithelium: implications for anosmia and upper respiratory SARS-COV-2 entry and replication. BioRxiv. 2020;00:10.101/20200508084996.

7. Walls AC, Park YJ, Tortorici MA, Wall A, McGuire AT, Veesler D. Structure, Function, and Antigenicity of the SARS-CoV-2 Spike Glycoprotein. Cell. 2020;181(2):281-92.

8. Patel BA, Verma A. Ashish Verma; Nasal ACE2 Levels and COVID19 in Children. JAMA. 2020;223(23):2386-7.

9. Kuba K, Imai Y, Rao S, Gao H, Guo F, Guan B. A crucial role of angiotensin converting enzyme 2 (ACE2) in SARS coronavirusinduced lung injury. Nat Med. 2005;11(8):875-9.

10. Li SR, Tang ZJ, Li ZH, Liu X. Searching therapeutic strategy of new coronavirus pneumonia from angiotensin-converting enzyme 2 : the target of COVID-19 and SARS-CoV. Eur J Clin Microbiol Infect Dis. 2020;39(6):1021-6.

11. Xu H, Zhong L, Deng J, Peng J, Dan H, Zeng X, et al. High expression of ACE2 receptor of 2019-nCoV on the epithelial cells of oral mucosa. Int J Oral Sci. 2020;12(1):1-5.

12. Day M. Covid-19: identifying and isolating asymptomatic people helped eliminate virus in Italian village. BMJ. 2020;368:1165.

13. Vofoa G, Brodieb R, Grossa M. Nasal lavage containing AngiotensinConverting Enzyme-2 agonist can prevent and reduce viral load in COVID-19. Med Hypotheses. 2020;144:110207.

14. Vickers C, Hales P, Kaushik V. Hydrolysis of biological peptides by human angiotensin-converting enzyme-related carboxypeptidase. $J$ Biol Chem. 2002;277:14838-43.

15. Long $\mathrm{C}, \mathrm{Xu} \mathrm{H}$, Shen Q. Diagnosis of the Coronavirus disease (COVID-19): rRTPCR or CT? Eur J Radiol. 2020;126:108961.

\section{Author biography}

Badrinarayan Mishra Professor

Orcid Id: https://orcid.org/0000-0001-6956-0469

S C Mohapatra Former HOD (BHU), Presently Academic Adviser \& Consultant

Cite this article: Mishra B, Mohapatra SC. Nasal ACE 2 receptors' the gateway to COVID 19?. J Community Health Manag 2020;7(3):68-69. 